\title{
Altered macrophage function contributes to colitis in mice defective in the phosphoinositide-3 kinase subunit p110ס
}

\author{
Jennifer K. Uno ${ }^{1,2}$, Kavitha N. Rao ${ }^{3}$, Katsuyoshi Matsuoka ${ }^{1}$, Shehzad Z. Sheikh ${ }^{1,2}$, Taku \\ Kobayashi $^{1}$, Fengling $\mathrm{Li}^{1,2}$, Erin C. Steinbach ${ }^{1,2}$, Antonia R. Sepulveda ${ }^{4}$, Bart \\ Vanhaesebroeck $^{5}$, R Balfour Sartor ${ }^{1,2}$, and Scott E. Plevy ${ }^{1,2}$ \\ ${ }^{1}$ Department of Medicine, University of North Carolina School of Medicine, Chapel Hill, NC 27599, \\ USA. \\ 2Department of Microbiology and Immunology, University of North Carolina School of Medicine, \\ Chapel Hill, NC 27599, USA. \\ ${ }^{3}$ Department of Immunology, University of Pittsburgh School of Medicine. Pittsburgh, PA 15213, \\ USA. \\ ${ }^{4}$ Department of Pathology, University of Pennsylvania School of Medicine, Philadelphia, PA, USA \\ ${ }^{5}$ Centre for Cell Signalling, Institute of Cancer, Queen Mary University of London, Charterhouse \\ Square, London, UK
}

\begin{abstract}
Background and Aims-Innate immune responses are crucial for host defense against pathogens, but need to be tightly regulated to prevent chronic inflammation. Initial characterization of mice with a targeted inactivating mutation in the p110d subunit of phosphoinositide 3-kinase (PI3K $\mathrm{p} 110 \delta^{\mathrm{D} 910 \mathrm{~A} / \mathrm{D} 910 \mathrm{~A}}$ ) reveal defects in $\mathrm{B}$ - and T-cell signaling and chronic colitis. Here, we further characterize features of inflammatory bowel diseases (IBD) in these mice and investigate underlying innate immune defects.
\end{abstract}

Methods-Colons and macrophages from PI3K $110 \delta^{\mathrm{D} 910 \mathrm{~A} / \mathrm{D} 910 \mathrm{~A}}$ mice were evaluated for colonic inflammation and innate immune dysfunction. Colonic p1 $10 \delta$ mRNA expression was examined in IL-10 $0^{-/-}$and wild type (WT) germ free (GF) mice during transition to a conventional microbiota. To assess polygenic impact on colitis development, $\mathrm{p} 110 \delta^{\mathrm{D} 910 \mathrm{~A} / \mathrm{D} 910 \mathrm{~A}}$ mice were backcrossed to IL- $10^{-/-}$mice.

Results-A mild spontaneous colitis was demonstrated in PI3K p1108 $8910 \mathrm{~A} / \mathrm{D} 910 \mathrm{~A}$ mice at 8 weeks with inflammation increasing with age. An inflammatory mucosal and systemic cytokine profile was characterized by expression of IL-12/23. In PI3K p1 $10 \delta^{\mathrm{D} 910 \mathrm{~A} / \mathrm{D} 910 \mathrm{~A}}$ macrophages, augmented toll-

(C) 2010 The American Gastroenterological Association. Published by Elsevier Inc. All rights reserved.

Correspondence: Scott E. Plevy, MD, Inflammatory Bowel Disease Center, 103 Mason Farm Road, Chapel Hill, North Carolina, scott_plevy@med.unc.edu, Phone: (919) 966-4405, Fax: (919) 843-2585.

Publisher's Disclaimer: This is a PDF file of an unedited manuscript that has been accepted for publication. As a service to our customers we are providing this early version of the manuscript. The manuscript will undergo copyediting, typesetting, and review of the resulting proof before it is published in its final citable form. Please note that during the production process errors may be discovered which could affect the content, and all legal disclaimers that apply to the journal pertain.

Contributions of Authors: Study concept and design (JKU, KNR, SEP); Acquisition of data (JKU, KNR, KM, SZS, FL, ECS, ARS, SEP, TK); Analysis and interpretation of data (JKU, KNR, KM, SZS, FL, ARS, SEP, TK); Drafting of the manuscript (JKU, KNR, ECS, BV, SEP); Critical revision of the manuscript for important intellectual content (JKU, KNR, BV, SEP); statistical analysis (JKU, SEP); Obtained funding (JKU, SZS, KM, RBS, SEP); Technical or material support (FL, BV, RBS); study supervision (RBS, SEP)

Conflict of Interest: None of the authors listed above have any conflicts of interest to disclose. 
like receptor signaling and defective bactericidal activity are observed. Consistent with an important homeostatic role for PI3K p110d, WT mice raised in a GF environment markedly upregulated colonic

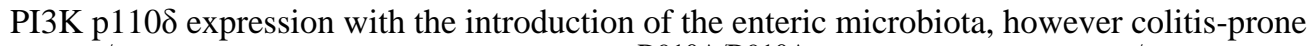
IL-10 $0^{-/-}$mice do not. Moreover, PI3K p $110 \delta^{\mathrm{D} 910 \mathrm{~A} / \mathrm{D} 910 \mathrm{~A}}$ mice crossed to IL- $10^{-/-}$mice developed severe colitis at an early age.

Conclusions-This study describes a novel model of experimental colitis which highlights the importance of PI3K p1108 in maintaining mucosal homeostasis and could provide insight into the pathogenesis of human IBD.

\section{Keywords}

inflammatory bowel diseases; innate immunity; PI3-kinase; enteric microbiota

\section{INTRODUCTION}

The pathogenesis of the human inflammatory bowel diseases (IBD) Crohn's disease (CD) and ulcerative colitis (UC) is complex, with abnormal immune responses in genetically susceptible individuals eliciting uncontrolled intestinal inflammation1. Genetic variants that confer CD susceptibility highlight the importance of innate immune interactions with the enteric microbiota in controlling inflammation1. Commensal and pathogenic bacteria are recognized through conserved molecular microbial patterns by pattern-recognition receptors (PRRs), of which toll-like receptors (TLRs) form integral components2. Signaling through TLRs leads to the activation of NF-kB, culminating in the induction of inflammatory cytokines including IL-12/23 and TNF. This inflammatory response is essential for the eradication of infectious microorganisms; however, excessive and prolonged activation can be detrimental to the host. Although mechanisms by which the host distinguishes commensal from pathogenic bacteria are not well defined, under normal conditions TLR signaling initiated by the enteric microbiota is protective 3 .

Phosphoinositide-3 kinases (PI3Ks) have emerged as important regulators of TLR signaling 4 , 5. Class $\mathrm{I}_{\mathrm{A}} \mathrm{PI} 3 \mathrm{Ks}$ are a family of heterodimeric enzymes consisting of a regulatory subunit (p85, p55 or p50) and a catalytic subunit (p110 $\alpha, \mathrm{p} 110 \beta, \mathrm{p} 110 \delta)^{6}$. While $\mathrm{p} 110 \alpha$ and $\mathrm{p} 110 \mathrm{~b}$ are expressed ubiquitously, the p110 Sisoform is highly expressed in leukocytes7. The clearest role of PI3K in chronic inflammation is described in a mouse harboring a point mutation in the $\mathrm{p} 110 \delta$ catalytic subunit of PI3K $\left(\mathrm{p} 110 \delta^{\mathrm{D} 910 \mathrm{~A} / \mathrm{D} 910 \mathrm{~A}}\right)^{8}$. These mice demonstrate B- and T-cell defects including improper maturation, defective antigen receptor signaling and impaired humoral immune responses. Notably, these mice spontaneously develop chronic segmental colonic inflammation.

However, effects of the PI3K p110§subunit on innate immune responses in mucosal inflammation remain uncharacterized. In this study, we further describe the development of chronic IBD in PI3K p1 10 $\delta^{\mathrm{D} 910 \mathrm{~A} / \mathrm{D} 910 \mathrm{~A}}$ mice and investigate the role of PI3K $\mathrm{p} 110 \delta$ in the regulation of TLR signaling and bactericidal pathways in macrophages.

\section{MATERIALS AND METHODS}

\section{Mice}

PI3K p1 10 $\delta^{\mathrm{D} 910 \mathrm{~A} / \mathrm{D} 910 \mathrm{~A}}$ mice were on the C57BL/6 background. C57BL/6 wild type and IL-10 $0^{-/-}$mice were obtained from Jackson Laboratories. Mice were housed in specific pathogen free conditions (SPF) in accordance with guidelines from the American Association for Laboratory Animal Care and Research. Germ free (GF) 8-week-old 129 Sv/Ev WT and IL- $10^{-/-}$mice were provided by the University of North Carolina Gnotobiotic Facility. Mice 
were colonized with SPF enteric microbiota at 8-weeks of age with a microbiota isolated from WT mice raised in SPF conditions ${ }^{9}$. PI3K $\mathrm{p} 110 \delta^{\mathrm{D} 910 \mathrm{~A} / \mathrm{D} 910 \mathrm{~A}}$ and IL- $10^{-1-}$ homozygous mice were crossed and offspring were genotyped for PI3K p $110 \delta^{\mathrm{D} 910 \mathrm{~A} / \mathrm{D} 910 \mathrm{~A}}$ and $\mathrm{IL}-10^{-/-}$ mutations. For F2 breeding, mice homozygous for one mutation and heterozygous for the other mutation were bred and mice homozygous for both PI3K $\mathrm{K} 110 \delta^{\mathrm{D} 910 \mathrm{~A} / \mathrm{D} 910 \mathrm{~A}}$ and $\mathrm{IL}-10^{-1-}$ were identified. All experimental mice were genotyped by PCR screening prior to tissue collection and littermates used as controls. The Institutional Animal Care and Use Committee of the University of Pittsburgh and the University of North Carolina approved all methods used in this study.

\section{Reagents}

Flagellin was purchased from Invivogen (San Diego, Ca). CpG DNA was obtained from Integrated DNA Technologies (Coralville, IA). Synthetic bacterial lipoprotein (sBLP) was purchased from EMC Microcollections (Tübingen, Germany). Peptidoglycan (PGN) and Lipopolysaccharide (LPS) from Salmonella enteritidis was purchased from Sigma (St. Louis, Mo). LPS was repurified by modified phenol extraction as previously described ${ }^{10}$. GM-CSF, and M-CSF were obtained from Peptotech Inc (Rocky Hill, NJ) and IFN-g was purchased from R \& D Systems (Minneapolis, MN).

\section{Cell isolation}

Splenocytes and bone marrow-derived macrophages (BMMs) were cultured as described ${ }^{11}$. Lamina propria mononuclear cells (LPMCs) were isolated from mouse colons by an enzymatic method as previously described12. LPMCs were separated into CD11 $\mathrm{b}^{+}$cells using antiCD11b microbeads (Miltenyi Biotec, Auburn, CA).

\section{ELISAs}

Murine IL-12 p40, IL-12 p70, IL-10, IFN- $\gamma$ and TNF immunoassay kits (R \& D Systems) and IL-23 (eBioscience) were used according to manufacturers' instructions. IL-17, MIP1a, RANTES, KC and G-CSF levels were determined by multiplex ELISA (Luminex). Phosphorylation levels of pAKT was determined using a cell-based ELISA (Superarray Bioscience Corporation).

\section{Western blot}

Western blot analyses were performed on whole cell extracts as described ${ }^{11}$. Antibodies to phospho (p)-JNK, p-p38, p-ERK, JNK2, p38, ERK, NF-kB p65, and PI3K p110 $\delta$ were obtained from Santa Cruz Biotechnology (Santa Cruz, CA), p-p65 was obtained from Cell Signaling (Danvers, MA 01923)

\section{Nitrite Determination}

Nitrite was assayed by a standard Greiss Reaction adapted to a microplate system.

\section{Real-time RT PCR analysis}

Quantitative real-time RT-PCR was performed as described ${ }^{13}$. Primer sequences are available on request.

\section{Colonic tissue explant cultures and histology}

Colonic explant cultures were performed as described previously ${ }^{13}$. Slides were prepared for hematoxylin and eosin staining and histologic analysis was performed by a pathologist blinded to the study groups (A.R.S.) using established criteria for IL- $10^{-/-}$mice (and PI3K

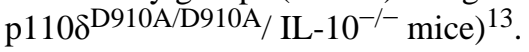




\section{Histologic scoring of PI3K p1108 ${ }^{\mathrm{D} 910 \mathrm{~A} / \mathrm{D} 910 \mathrm{~A}}$ mice}

A histological scoring system was developed to assess colonic inflammation based on the characteristic of this model. The criteria used to classify histology into grades 0 to 4 were as follows: Grade 0 was defined as (a) presence of 1 or less mitosis in the colonic crypts per 10 high power fields (HPF), (b) no epithelial hyperplasia, and (c) no neutrophils in the lamina propria. Grade 1 was established if less than two of the following criteria were found: (a) presence of epithelial hyperplasia, (b) presence of more than 2 mitosis/10 HPF in the colonic crypts, (c) any apoptotic body in the colonic crypts, (d) Infiltration by neutrophils in the lamina propria, (e) infiltration by lymphocytes and/or plasma cells in the lamina propria, (d) infiltration by lymphocytes and/or plasma cells and neutrophils in the lamina propria, (g) less than $30 \%$ of colonic crypts showing intraepithelial lymphocytes (IELs). If there were two or more of the criteria for grade 1, grade 2 was attributed. Grade 3 was defined as (a) any of the criteria for grade 2 was present and there were more than $30 \%$ of IELs involving the colonic crypts per $10 \mathrm{HPF}$, (b) or there was submucosal inflammation. Grade 4 was attributed when any of the criteria for grade 3 was identified together with the presence of crypt abscesses and/or mucosal ulcers. Histopathologic analysis of WT mice revealed no or minimal mucosal inflammation with one or less mitosis per $10 \mathrm{HPF}$, and was scored as grade 0 in the majority of mice, or 1 .

\section{Gentamicin Protection Assay}

Bacterial invasion was measured by gentamicin protection assays ${ }^{14}$. Briefly, BMMs were infected with bacteria with a multiplicity of infection of 10 bacteria per cell in antibiotic free media. Cells were incubated with the bacteria for 2 hours at $37^{\circ} \mathrm{C}$ with $5 \% \mathrm{CO}_{2}$. LPS $(100 \mathrm{ng} /$ $\mathrm{mL})$ and $\mathrm{IFN}-\mathrm{g}(10 \mathrm{ng} / \mathrm{ml})$ were added 2 hours prior to bacteria where indicated. Cells were then washed twice with PBS and fresh media containing $100 \mathrm{mg} / \mathrm{ml}$ of gentamicin was added for an hour. Cells were lysed with $1 \%$ Triton $X$ and samples were diluted and plated on LB agar plates to determine the number of colony-forming units.

\section{Bacterial DNA Isolation}

Total DNA was extracted from splenocytes and mesenteric lymph nodes as outlined in Frank et $\mathrm{al}^{15}$. Universal bacteria primer sequences were obtained from Horz, et a ${ }^{16}$. Bacterial DNA expression was determined by real-time PCR and expression was normalized to host GAPDH and represented as relative expression to control.

\section{Statistical Analysis}

Statistical significance from experiments in cells was determined using student t-test or oneway ANOVA. Statistical significance for in vivo data was assessed by the Mann-Whitney U test (SPSS, Chicago, IL, USA) with Bonferroni correction.

\section{RESULTS}

\section{PI3K p1108D910A/D910A mice develop chronic colitis}

Macroscopically, colons from 16-week-old PI3K p1108 $\delta^{\mathrm{D} 910 \mathrm{~A} / \mathrm{D} 910 \mathrm{~A}}$ mice were shorter in length and thicker than those from wild type (WT) with ten percent of mutant mice developing rectal prolapse (data not shown). To characterize histological features and progression of colitis, colonic sections were examined from 6 to 45 weeks of age (Figure 1A). A histological scoring system was developed based on features of this model to assess the severity of inflammation (see Materials and Methods). Colitis was characterized by increased colonic epithelial apoptotic bodies and a marked increase in the number of mitoses in the colonic crypts. There was an increase in lamina propria lymphocytes and neutrophils (Figure 1C, left). The colonic crypt architecture was generally well preserved with focal disruption of the tubular architecture associated with crypt abscesses (Figure 2C, middle black arrow). Histologic 
inflammation was detected starting at 8 weeks of age (Figure 1B). The percentage of fields demonstrating no histological inflammation (grade 0) significantly decreased and the percentage of fields with marked inflammation (grade 3 to 4 ) significantly increased (Figure $1 \mathrm{~A} \& \mathrm{~B}$ ) with age. A reduction in goblet cells was observed in older mice (Figure 1C, right). A unique feature was the presence of numerous intraepithelial lymphocytes (IELs) in the colonic epithelium (Figure 1C, right, white arrows). Immunohistochemical analysis revealed the presence of numerous $\mathrm{CD}^{+}$IELs in the colonic crypts of mutant mice compared to WT mice (Supplemental Figure 1).

\section{PI3K p1108D910A/D910A mice display an exaggerated mucosal and systemic Th1/ Th17 cytokine profile}

Colonic explants from $\mathrm{p} 110 \delta^{\mathrm{D} 910 \mathrm{~A} / \mathrm{D} 910 \mathrm{~A}}$ mice secreted significantly elevated amounts of inflammatory cytokines IL-12 p40, IL-12 p70, TNF, IFN-g and IL-17 (Figure 1D), as well as the growth factors and chemokines G-CSF, MIP1a, RANTES and KC (Supplemental Figure 2). LPS-stimulated PI3K p110 $\delta^{\mathrm{D} 910 \mathrm{~A} / \mathrm{D} 910 \mathrm{~A}}$ splenocytes secreted elevated levels of IL-12 p40 (Figure 2A) and TNF (Supplemental Figure 3) compared to WT splenocytes.

$\mathrm{CD}_{1} \mathrm{~b}^{+}$lamina propria mononuclear cells (LPMC), comprising macrophages and dendritic cells, were isolated from colons of $\mathrm{p} 110 \delta^{\mathrm{D} 910 \mathrm{~A} / \mathrm{D} 910 \mathrm{~A}}$ and WT mice. PI3K p1108 ${ }^{\mathrm{D} 910 \mathrm{~A} / \mathrm{D} 910 \mathrm{~A}} \mathrm{CD} 11 \mathrm{~b}^{+}$colonic LPMCs produced lower basal levels of IL-10 relative to WT LPMCs (Figure 2B). Moreover, p1108 ${ }^{\mathrm{D} 910 \mathrm{~A} / \mathrm{D} 910 \mathrm{~A}} \mathrm{CD} 11 \mathrm{~b}^{+}$LPMCs activated with heat killed $E$. coli expressed increased levels of IL-12 p40 and decreased levels of IL-10 compared to wild type CD11 $\mathrm{b}^{+}$cells (Figure $2 \mathrm{~B} \& \mathrm{C}$ ). Furthermore, CD11b ${ }^{+}$LPMC from PI3K $\mathrm{p} 110 \delta^{\mathrm{D} 910 \mathrm{~A} / \mathrm{D} 910 \mathrm{~A}}$ mice demonstrated upregulation of numerous activation markers, TLR4, and CD14 (Supplemental Figure 4B) compared to WT CD11 b ${ }^{+}$LPMC, consistent with in vivo activation and/or recruitment of macrophages during the development of colitis.

\section{PI3K p1108 ${ }^{\text {D910A/D910A }}$ macrophages are hyperresponsive to TLR signaling}

The role of PI3K p110@in the regulation of IL-12 p40 gene expression was next studied as a biologically relevant target of TLR signaling in macrophages. BMMs from PI3K $\mathrm{p} 110 \delta^{\mathrm{D} 910 \mathrm{~A} / \mathrm{D} 910 \mathrm{~A}}$ mice secreted significantly greater amounts of IL-12 $\mathrm{p} 40$ protein with LPS stimulation compared to WT BMMs (Figure 2D). Although the kinetics of IL-12 p40 induction were similar between WT and $\mathrm{p} 110 \delta^{\mathrm{D} 910 \mathrm{~A} / \mathrm{D} 910 \mathrm{~A}} \mathrm{BMMs}$, the magnitude of induction at each time point was significantly greater in the latter. PI3K p1 $10 \delta^{\mathrm{D} 910 \mathrm{~A} / \mathrm{D} 910 \mathrm{~A}}$ and WT BMMs revealed similar kinetics of IL-12 p40 (Ill2b) mRNA expression that peaked 4 hours poststimulation and significantly attenuated by 12 hours. However, there was increased magnitude of expression at all time points until 12 hours in $\mathrm{p} 110 \delta^{\mathrm{D} 910 \mathrm{~A} / \mathrm{D} 910 \mathrm{~A}}$ BMMs (Figure 2E).

Next, BMMs from WT and $\mathrm{p} 110 \delta^{\mathrm{D} 910 \mathrm{~A} / \mathrm{D} 910 \mathrm{~A}}$ mice were stimulated with TLR9 (CpG), TLR2 (synthetic bacterial lipoprotein-sBLP) or TLR5 (flagellin) ligands. IL-12 p40, IL-12 p70, IL-23 and nitric oxide (NO) production were assessed. PI3K p1108 ${ }^{\mathrm{D} 910 \mathrm{~A} / \mathrm{D} 910 \mathrm{~A}} \mathrm{BMMs}$ produced enhanced amounts of inflammatory cytokines and nitric oxide in response to multiple TLR ligands (Figure 3). There were no differences in cell surface phenotypic or activation marker expression between PI3K p1 $10 \delta^{\mathrm{D} 910 \mathrm{~A} / \mathrm{D} 910 \mathrm{~A}}$ and WT BMMs, including TLR4 and CD14 (Supplemental Figure 4A), suggesting that augmented TLR signaling in PI3K p1 $10 \delta^{\mathrm{D} 910 \mathrm{~A} / \mathrm{D} 910 \mathrm{~A}}$ BMMs is secondary to intrinsic defects in TLR signaling pathways and not a result of a heightened activation state or increased expression of TLRs or TLR co-receptors.

\section{PI3K p1108D910A/D910A macrophages display enhanced MAPK activation}

PI3K signaling is significantly diminished in PI3K p1 $10 \delta^{\mathrm{D} 910 \mathrm{~A} / \mathrm{D} 910 \mathrm{~A}} \mathrm{BMMs}$ as demonstrated by decreased phosphorylation of the PI3K downstream target Akt in LPS or sBLP activated PI3K p1108 ${ }^{\mathrm{D} 910 \mathrm{~A} / \mathrm{D} 910 \mathrm{~A}}$ BMMs compared to WT BMMs (Figure 4A). TLR signaling in 
macrophages is positively regulated by the MAP kinases $\mathrm{p} 38$ and JNK ${ }^{17}$, 18; and negatively regulated by the ERK MAP kinase pathway ${ }^{18}$. LPS-activated $\mathrm{p} 110 \delta^{\mathrm{D} 910 \mathrm{~A} / \mathrm{D} 910 \mathrm{~A}} \mathrm{BMMs}$ displayed a different kinetic pattern of JNK and p38 MAP kinase activation compared to WT macrophages (Figure 4B), with earlier activation and enhanced phosphorylation of p38 MAP kinase. There were no significant differences in ERK activation between $\mathrm{p} 110 \delta^{\mathrm{D} 910 \mathrm{~A} / \mathrm{D} 910 \mathrm{~A}}$ and WT BMMs. Likewise, there was no difference in magnitude or kinetics of NF-kB p65 phosphorylation in LPS-stimulated WT and PI3K p1108 ${ }^{\text {D910A/D910A }}$ BMMs (Supplemental Figure 5A).

\section{PI3K p1108D910A/D910A macrophages demonstrate decreased bactericidal activity}

To determine whether PI3K p110d ${ }^{\mathrm{D} 910 \mathrm{~A} / \mathrm{D} 910 \mathrm{~A}}$ macrophages are defective in eradicating intracellular bacteria, gentamicin protection assays were performed with the commensal enteric bacteria K12 E. coli, NC101 E. coli, and the invasive enteric organism S. typhimurium. NC101 E. coli is a colitogenic bacterial strain isolated from IL-10 $0^{-/-}$mice ${ }^{19}$. PI3K p1108 ${ }^{\mathrm{D} 910 \mathrm{~A} / \mathrm{D} 910 \mathrm{~A}}$ BMMs display decreased bactericidal activity when infected with K12 E. coli, NC101 E. coli, and S. typhimurium (Figure 5A, right). Moreover, bacterial colonies recovered 1 hour following infection were not significantly different from WT BMMs (Figure $5 \mathrm{~A}$, left). Additionally, WT and PI3K p110 $\delta^{\mathrm{D} 910 \mathrm{~A} / \mathrm{D} 910 \mathrm{~A}}$ BMMs were infected for 1 hour with K12 E. coli, washed and permeabilized, and then immunostained with anti-E. coli LPS antibodies. No immunoreactivity was demonstrated in non-permeabilized cells, and wild type and PI3K p1 $10 \delta^{\mathrm{D} 910 \mathrm{~A} / \mathrm{D} 910 \mathrm{~A}}$ BMMs demonstrated similar numbers of intracellular bacteria, demonstrating that uptake/phagocytosis is not defective in PI3K $\mathrm{p} 110 \delta^{\mathrm{D} 910 \mathrm{~A} / \mathrm{D} 910 \mathrm{~A}} \mathrm{BMMs}$ (Supplemental Figure 6). Culture supernatants showed a marked increase in IL-12 p40 protein in PI3K p1108 ${ }^{\mathrm{D} 910 \mathrm{~A} / \mathrm{D} 910 \mathrm{~A}}$ BMMs that inversely correlated with bactericidal activity (Figure $5 \mathrm{~B})$.

Bacterial products such as LPS and inflammatory cytokines like IFN-g activate macrophages and augment bactericidal responses ${ }^{20,21}$. Bactericidal activity was significantly enhanced in WT BMMs treated with LPS and IFN- $\tilde{\gamma}$ This augmentation was completely absent in PI3K p1 108 ${ }^{\mathrm{D} 910 \mathrm{~A} / \mathrm{D} 910 \mathrm{~A}}$ BMMs (Figure 5C).

To obtain in vivo evidence of defective enteric bacterial clearance in PI3K $\mathrm{p} 110 \delta^{\mathrm{D} 910 \mathrm{~A} / \mathrm{D} 910 \mathrm{~A}}$ mice, the presence of bacterial DNA in WT and $\mathrm{p} 110 \delta^{\mathrm{D} 910 \mathrm{~A} / \mathrm{D} 910 \mathrm{~A}}$ spleens and mesenteric lymph nodes (MLNs) was determined using universal bacterial $16 \mathrm{~S}$ ribosomal RNA (rRNA) gene primers. Markedly increased bacterial rDNA was detected in spleens and MLNs of PI3K p1 $10 \delta^{\mathrm{D} 910 \mathrm{~A} / \mathrm{D} 910 \mathrm{~A}}$ mice compared to WT mice, consistent with defective bacterial clearance and/or increased bacterial translocation (Figure 5D).

\section{The enteric microbiota induce colonic PI3K p110ס expression in WT but not in colitisprone IL-10 $10^{-/}$mice}

Colonic expression of PI3K p110 $\delta$ was studied in WT and colitis-prone IL- $10^{-1-}$ mice raised in a GF environment and then colonized with a specific pathogen free microbiota. PI3K p110 mRNA (Figure 6A) expression increased in WT mice beginning 7 days following colonization and was most strongly upregulated 14 days following transition. This increase was specific for the p110d isoform, as colonic mRNA expression for the p55a and $\mathrm{p} 85$ subunits were not significantly altered (Figure 6B). This robust increase in colonic p110MRNA was not observed in GF IL-10 ${ }^{-1-}$ mice transitioned to a conventional microbiota (Figure 6A). These results, in a well-established model of experimental colitis, support the hypothesis that PI3K p110 is an important homeostatic pathway limiting the extent and duration of intestinal inflammation. 
Additionally, this result suggested that IL-10 might be an important cofactor for expression of p110 by enteric bacteria. Therefore, induction of p110 $\delta$ was assessed in LPS activated WT and IL-10 $10^{-1-}$ BMMs. LPS-activated IL- $10^{-/-}$BMMs demonstrated decreased PI3K p1 $10 \delta^{\mathrm{D} 910 \mathrm{~A} / \mathrm{D} 910 \mathrm{~A}}$ mRNA (Figure 6C, left) and protein expression compared to WT BMMs (Figure 6C, right). Moreover, PI3K p1 $10 \delta$ mRNA induction in LPS-activated BMMs is through a MyD88 dependent pathways as significantly less p110 $\delta$ mRNA and protein was observed in MyD88 ${ }^{-1}$ BMMS compared to WT BMMS (Supplemental Figure 5B), confirming that PI3K p1108 induction is through the canonical TLR signaling pathway.

\section{IL -10/PI3K p1108D910A/D910A mice exhibit severe colitis at an early age}

The phenotype of murine and human IBDs are influenced by polygenic contributions. In PI3K $\mathrm{p} 110 \mathrm{~d}^{\mathrm{D} 910 \mathrm{~A} / \mathrm{D} 910 \mathrm{~A}}$ and IL-10 $10^{-1}$ mice on the C57BL/6 background, the phenotype of colitis is relatively mild. Moreover, partial but not complete abrogation of colonic PI3K p110 expression was observed in GF IL-10 $0^{-1}$ mice transitioned to a microbiota (Figure 6A). Therefore, to address whether a combined genetic defect in p110 $\delta$ and IL-10 alters the

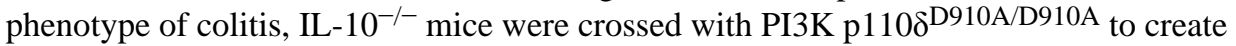
IL-10-I-/PI3K p $110 \delta^{\mathrm{D} 910 \mathrm{~A} / \mathrm{D} 910 \mathrm{~A}}$ mice. While 4 week old PI3K p110 $\delta^{\mathrm{D} 910 \mathrm{~A} / \mathrm{D} 910 \mathrm{~A}}$ and $\mathrm{IL}-10^{-1-}$ mice do not demonstrate colonic inflammation, IL-10 $0^{-/-} / \mathrm{PI} 3 \mathrm{~K}$ p $110 \delta^{\mathrm{D} 910 \mathrm{~A} / \mathrm{D} 910 \mathrm{~A}}$ mice developed severe colitis and were notably smaller in size. Gross colonic appearance showed $100 \%$ disease penetrance with all mice developing colitis by 4 weeks of age and over $50 \%$ displaying severe inflammatory changes (Supplemental Figure 7). Colitis scores from IL-10-/- $/ \mathrm{PI} 3 \mathrm{~K}$ p $110 \delta^{\mathrm{D} 910 \mathrm{~A} / \mathrm{D} 910 \mathrm{~A}}$ mice were significantly higher than age-matched PI3K p1108 ${ }^{\mathrm{D} 910 \mathrm{~A} / \mathrm{D} 910 \mathrm{~A}}, \mathrm{IL}-10^{-1-}$, and WT mice (Figure 7A). Intestinal explant cultures demonstrated increased secretion of IL-12 p40, IL-12 p70 and IL-23 in from IL-10 $0^{-/-} / \mathrm{PI} 3 \mathrm{~K}$ $\mathrm{p} 110 \delta^{\mathrm{D} 910 \mathrm{~A} / \mathrm{D} 910 \mathrm{~A}}$ mice compared to age-matched $\mathrm{IL}-10^{-/-}$and PI3K $\mathrm{p} 110 \delta^{\mathrm{D} 910 \mathrm{~A} / \mathrm{D} 910 \mathrm{~A}}$ mice (Figure 7B-D).

\section{DISCUSSION}

This study describes an important role for the activity of the PI3K p1108 isoform in the regulation of TLR signaling and bactericidal pathways in macrophages. Notably, PI3K p110.plays a critical role in intestinal homeostasis in experimental colitis models.

Class $\mathrm{I}_{\mathrm{A}}$ PI3Ks are heterodimers consisting of a catalytic subunit (p110 $\left.\alpha, \mathrm{p} 110 \beta, \mathrm{p} 110 \delta\right)$ which complexes with one of five regulatory units (p85 isoforms). While p110 $\alpha$ and $\mathrm{p} 110 \beta$ are ubiquitously expressed, p110 expression is low or absent in most cell types but is abundantly expressed in leukocytes ${ }^{22}$. PI3K p1108 $\delta^{\mathrm{D} 910 \mathrm{~A} / \mathrm{D} 910 \mathrm{~A}}$ mice have significant defects in B cell antigen receptor signaling, substantial declines in immunoglobulin levels, as well as diminished numbers of immature and mature B cells. Interestingly, in B cells, p110 $\delta$ regulates TLRinduced proliferation ${ }^{23}$. PI3K $\mathrm{p} 110 \delta$ also suppresses TLR9-induced IL-12 production in B cells, inhibiting a Th1-skewed response ${ }^{24}$. T cell functional abnormalities have been described in PI3K p1 108 ${ }^{\mathrm{D} 910 \mathrm{~A} / \mathrm{D} 910 \mathrm{~A}}$ mice, including defects in $\mathrm{T}$ cell signaling through the $\mathrm{T}$ cell receptor, and defective $\mathrm{T} \mathrm{CD} 4^{+} / \mathrm{CD} 25^{+} / \mathrm{Foxp}^{+} \mathrm{T}$ regulatory cell function, recently demonstrated in an adoptive transfer model of colitis ${ }^{25}$.

We provide the first detailed characterization of spontaneously occurring colitis in PI3K p1108 ${ }^{\mathrm{D} 910 \mathrm{~A} / \mathrm{D} 910 \mathrm{~A}}$ mice. Immunologically, an exuberant inflammatory Th1 and Th17 cytokine profile was observed in the colon and systemically. Several characteristics of colitis are reminiscent of features of human IBD, including leukocytic and neutrophilic infiltrates, intestinal epithelial cell damage, and goblet cell depletion. Although older mice had more significant histologic inflammation, the majority of mice demonstrated colonic inflammatory changes that were not severe in nature. However, genetic background is an important modifier of phenotype in murine experimental colitis and human IBD. For instance, IL-10 ${ }^{-/-}$mice on 
the C57BL/6 background have a relatively mild colitis phenotype. In fact, in our comparative studies, the incidence and severity of histological inflammation and intestinal inflammatory cytokine secretion were similar in PI3K $\mathrm{p} 110 \delta^{\mathrm{D} 910 \mathrm{~A} / \mathrm{D} 910 \mathrm{~A}}$ mice and age-matched IL-10 ${ }^{-/-}$ mice on the C57BL/6 background. As polygenic contributions and genetic background can alter phenotype, $\mathrm{IL}-10^{-1-}$ mice were backcrossed to PI3K p $110 \delta^{\mathrm{D} 910 \mathrm{~A} / \mathrm{D} 910 \mathrm{~A}}$ mice. Using a scoring system devised for IL- $10^{-/-}$mice, IL-10-/- $/ \mathrm{PI} 3 \mathrm{~K}$ p $110 \delta^{\mathrm{D} 910 \mathrm{~A} / \mathrm{D} 910 \mathrm{~A}}$ mice develop severe colitis and an exuberant mucosal inflammatory cytokine response at an early age compared to each of the founder strains. This finding implicates IL-10 and PI3K p110 $\delta$ as two important, non-redundant, homeostatic pathways that function in normal physiology to suppress intestinal inflammation directed against the enteric microbiota.

The importance of the enteric microbiota in the initiation of IBD is illustrated by $\mathrm{IL}-10^{-1-}$ mice, where the development of spontaneous colitis is dependent on the presence of the microbiota ${ }^{1}$. We show dramatically increased levels of PI3K p $110 \delta$ mRNA in the colon of WT GF mice transitioned to a microbiota. Importantly, augmented expression was not seen in transitioned colitis-prone IL- $10^{-1-}$ mice, which correlated with the development of intestinal inflammation. Strikingly similar findings were observed in LPS-activated BMMs from $\mathrm{IL}-10^{-/-}$and WT mice. These findings suggest that $\mathrm{p} 110 \delta$ regulation may be an important homeostatic pathway in other models of intestinal inflammation. Based on our results, PI3K induced through TLR signaling is an event that limits the extent and duration of TLR-activated of pro-inflammatory responses. In IL-10 deficiency, one mechanism for exuberant and

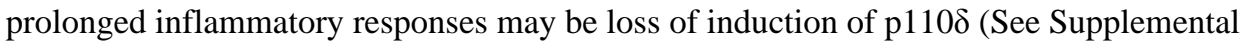
Figure 8 for model).

A prominent histological feature in $\mathrm{PI} 3 \mathrm{~K}$ p1 $10 \delta^{\mathrm{D} 910 \mathrm{~A} / \mathrm{D} 910 \mathrm{~A}}$ mice that is not characteristic of human Crohn's disease or ulcerative colitis is the presence of numerous intraepithelial lymphocytes. However, intraepithelial lymphocytosis is characteristic of three forms of human IBD; celiac disease, lymphocytic colitis and collagenous colitis 26,27 . Although the purpose of this study was to correlate the development of colitis with defects in innate immunity in PI3K $\mathrm{p} 110 \mathrm{~d}^{\mathrm{D} 910 \mathrm{~A} / \mathrm{D} 910 \mathrm{~A}}$ mice, a goal of future research will be to characterize the role of intraepithelial lymphocytes in this model.

PI3K $\mathrm{p} 110 \delta^{\mathrm{D} 910 \mathrm{~A} / \mathrm{D} 910 \mathrm{~A}}$ macrophages demonstrate heightened sensitivity to stimulation by TLR ligands. This finding underscores the importance of PI3K p110@in dampening TLR signaling and also suggests that aberrant regulation of innate immune responses could contribute to the development of colitis in PI3K p1 $10 \delta^{\mathrm{D} 910 \mathrm{~A} / \mathrm{D} 910 \mathrm{~A}}$ mice. Accumulating evidence has established the role of PI3K in the attenuation of TLR signaling $28^{-} 31$. For instance, mice with genetic deletion of the PI3K p $85 \alpha$ subunit display altered balance of Th1Th2 responses ${ }^{28}$, and dendritic cells produce enhanced levels of IL-12 in response to TLR2 (PGN), TLR4 (LPS) and TLR9 (CpG) ligands. However, these mice do not develop chronic colonic inflammation. It is possible that mice deficient in PI3K subunits demonstrate compensatory changes in expression and availability of regulatory subunits, which could affect phenotypic and functional analyses ${ }^{8}$. As we demonstrate in PI3K p $110 \delta^{\mathrm{D} 910 \mathrm{~A} / \mathrm{D} 910 \mathrm{~A}}$ mice, TLR activation in macrophages elicits an exuberant inflammatory response. However, TLR signaling in intestinal epithelial cells is protective against inflammation ${ }^{2}$. We speculate that the genetic defects in PI3K p1108 $\delta^{\mathrm{D} 910 \mathrm{~A} / \mathrm{D} 910 \mathrm{~A}}$ mice that lead to the development of colitis are limited to the hematopoietic compartment as p $110 \delta$ is not highly expressed in epithelial cells $^{32}$

Genetic variants linked to Crohn's disease include genes that mediate autophagy and phagosomal function ${ }^{1}$. Recent studies indicate the importance of PI3K signaling in phagosomal maturation and acidification, essential for optimal bacterial killing ${ }^{33,34}$. Here, we show that PI3K $110 \delta^{\mathrm{D} 910 \mathrm{~A} / \mathrm{D} 910 \mathrm{~A}}$ macrophages are less efficient than WT macrophages at eliminating 
enteric commensal and pathogenic enteric bacteria. Our results indicate that PI3K p110 necessary for phagocytosis of bacteria into the cell as there is no difference in bacterial survival following one hour of incubation with bacteria between wild-type and PI3K p1 $10 \delta^{\mathrm{D} 910 \mathrm{~A} / \mathrm{D} 910 \mathrm{~A}}$ macrophages. We also demonstrated that defective bactericidal activity in $\mathrm{PI} 3 \mathrm{~K}$ p110 $\delta^{\mathrm{D} 910 \mathrm{~A} / \mathrm{D} 910 \mathrm{~A}}$ macrophages is associated with increased inflammatory cytokine production. Additionally, PI3K p1 $10 \delta^{\mathrm{D} 910 \mathrm{~A} / \mathrm{D} 910 \mathrm{~A}}$ mice are defective at clearing enteric bacteria in vivo, suggesting that the inability of PI3K p1 10 $\delta^{\mathrm{D} 910 \mathrm{~A} / \mathrm{D} 910 \mathrm{~A}}$ macrophages to efficiently kill and clear microbes may contribute to prolonged inflammatory responses. However, macrophage function is not globally compromised in PI3K p110 $\delta^{\mathrm{D} 910 \mathrm{~A} / \mathrm{D} 910 \mathrm{~A}}$ mice. Indeed, the ability of macrophages and dendritic cells from PI3K p110 $\delta^{\mathrm{D} 910 \mathrm{~A} / \mathrm{D} 910 \mathrm{~A}}$ mice to produce NO and destroy intracellular Leishmania parasites was recently reported to be similar to WT mice ${ }^{2}$.

In summary, the PI3K p110 $\delta^{\mathrm{D} 910 \mathrm{~A} / \mathrm{D} 910 \mathrm{~A}}$ mouse is an interesting model for understanding the pathogenesis of human IBD as it provides an example of how a genetic defect in a specific intracellular signaling molecule can lead to global defects in innate and adaptive homeostatic pathways in the intestine. Furthermore, polygenic contributions alter the phenotype of colitis as IL-10-/- 1 I3K p $110 \delta^{\mathrm{D} 910 \mathrm{~A} / \mathrm{D} 910 \mathrm{~A}}$ mice develop severe colitis at a young age compared to the parent strains. This study describes aberrant innate immunity including exuberant TLR signaling and defective bactericidal activity in macrophages that contribute to the pathogenesis of colitis.

\section{Supplementary Material}

Refer to Web version on PubMed Central for supplementary material.

\section{Abbreviations}

$\begin{array}{ll}\text { BMM } & \text { bone-marrow derived macrophages } \\ \text { GF } & \text { germ-free } \\ \text { GM-CSF } & \text { granulocyte-macrophage colony-stimulating factor } \\ \text { IL } & \text { interleukin } \\ \text { LPMC } & \text { lamina propria mononuclear cells } \\ \text { LPS } & \text { lipopolysaccharide } \\ \text { M-CSF } & \text { macrophage colony-stimulating factor } \\ \text { NO } & \text { nitric oxide } \\ \text { NF-KB } & \text { nuclear factor kappa B } \\ \text { PRRs } & \text { pattern-recognition receptors } \\ \text { PGN } & \text { peptidoglycan } \\ \text { PI3K } & \text { phosphoinositide 3-kinase } \\ \text { SPF } & \text { specific pathogen free } \\ \text { SBLP } & \text { Synthetic bacterial lipoprotein } \\ \text { TNF } & \text { tumor necrosis factor alpha } \\ \text { TLR } & \text { toll-like receptor } \\ \text { WT } & \text { wild type }\end{array}$




\section{Acknowledgments}

This work was supported by NIH grants RO1 DK054452 (SEP), UNC Center for Gastrointestinal Biology and Disease P30 DK34987 (Histology Core, Gnotobiotic Core, and Immunotechnologies Core). SPIRE fellowship K12GM000678 (JKU) NRSA F32 DK083186 (SZS), and a Crohn's and Colitis Foundation of America Research Fellowship Award (KM).

\section{REFERENCES}

1. Xavier RJ, Podolsky DK. Unravelling the pathogenesis of inflammatory bowel disease. Nature 2007;448:427-434. [PubMed: 17653185]

2. Abreu MT. Toll-like receptor signalling in the intestinal epithelium: how bacterial recognition shapes intestinal function. Nat Rev Immunol 10:131-144. [PubMed: 20098461]

3. Rakoff-Nahoum S, Paglino J, Eslami-Varzaneh F, Edberg S, Medzhitov R. Recognition of commensal microflora by toll-like receptors is required for intestinal homeostasis. Cell 2004;118:229-241. [PubMed: 15260992]

4. Liew FY, Xu D, Brint EK, O'Neill LA. Negative regulation of toll-like receptor-mediated immune responses. Nat Rev Immunol 2005;5:446-458. [PubMed: 15928677]

5. Fukao T, Koyasu S. PI3K and negative regulation of TLR signaling. Trends Immunol 2003;24:358363. [PubMed: 12860525]

6. Vanhaesebroeck B, Leevers SJ, Ahmadi K, Timms J, Katso R, Driscoll PC, Woscholski R, Parker PJ, Waterfield MD. Synthesis and function of 3-phosphorylated inositol lipids. Annu Rev Biochem 2001;70:535-602. [PubMed: 11395417]

7. Vanhaesebroeck B, Welham MJ, Kotani K, Stein R, Warne PH, Zvelebil MJ, Higashi K, Volinia S, Downward J, Waterfield MD. P110delta, a novel phosphoinositide 3-kinase in leukocytes. Proc Natl Acad Sci U S A 1997;94:4330-4335. [PubMed: 9113989]

8. Okkenhaug K, Bilancio A, Farjot G, Priddle H, Sancho S, Peskett E, Pearce W, Meek SE, Salpekar A, Waterfield MD, Smith AJ, Vanhaesebroeck B. Impaired B and T cell antigen receptor signaling in p110delta PI 3-kinase mutant mice. Science 2002;297:1031-1034. [PubMed: 12130661]

9. Sellon RK, Tonkonogy S, Schultz M, Dieleman LA, Grenther W, Balish E, Rennick DM, Sartor RB. Resident enteric bacteria are necessary for development of spontaneous colitis and immune system activation in interleukin-10-deficient mice. Infect Immun 1998;66:5224-5231. [PubMed: 9784526]

10. Hirschfeld M, Ma Y, Weis JH, Vogel SN, Weis JJ. Cutting edge: repurification of lipopolysaccharide eliminates signaling through both human and murine toll-like receptor 2. J Immunol 2000;165:618622. [PubMed: 10878331]

11. Xiong H, Zhu C, Li F, Hegazi R, He K, Babyatsky M, Bauer AJ, Plevy SE. Inhibition of interleukin-12 p40 transcription and NF-kappaB activation by nitric oxide in murine macrophages and dendritic cells. J Biol Chem 2004;279:10776-10783. [PubMed: 14679201]

12. Kamada N, Hisamatsu T, Okamoto S, Sato T, Matsuoka K, Arai K, Nakai T, Hasegawa A, Inoue N, Watanabe N, Akagawa KS, Hibi T. Abnormally differentiated subsets of intestinal macrophage play a key role in Th1-dominant chronic colitis through excess production of IL-12 and IL-23 in response to bacteria. J Immunol 2005;175:6900-6908. [PubMed: 16272349]

13. Hegazi RA, Rao KN, Mayle A, Sepulveda AR, Otterbein LE, Plevy SE. Carbon monoxide ameliorates chronic murine colitis through a heme oxygenase 1-dependent pathway. J Exp Med 2005;202:17031713. [PubMed: 16365149]

14. Darfeuille-Michaud A, Boudeau J, Bulois P, Neut C, Glasser AL, Barnich N, Bringer MA, Swidsinski A, Beaugerie L, Colombel JF. High prevalence of adherent-invasive Escherichia coli associated with ileal mucosa in Crohn's disease. Gastroenterology 2004;127:412-421. [PubMed: 15300573]

15. Frank DN, St Amand AL, Feldman RA, Boedeker EC, Harpaz N, Pace NR. Molecular-phylogenetic characterization of microbial community imbalances in human inflammatory bowel diseases. Proc Natl Acad Sci U S A 2007;104:13780-13785. [PubMed: 17699621]

16. Horz HP, Vianna ME, Gomes BP, Conrads G. Evaluation of universal probes and primer sets for assessing total bacterial load in clinical samples: general implications and practical use in endodontic antimicrobial therapy. J Clin Microbiol 2005;43:5332-5337. [PubMed: 16208011] 
17. Zhu C, Gagnidze K, Gemberling JH, Plevy SE. Characterization of an activation protein-1-binding site in the murine interleukin-12 p40 promoter. Demonstration of novel functional elements by a reductionist approach. J Biol Chem 2001;276:18519-18528. [PubMed: 11279072]

18. Feng GJ, Goodridge HS, Harnett MM, Wei XQ, Nikolaev AV, Higson AP, Liew FY. Extracellular signal-related kinase (ERK) and p38 mitogen-activated protein (MAP) kinases differentially regulate the lipopolysaccharide-mediated induction of inducible nitric oxide synthase and IL-12 in macrophages: Leishmania phosphoglycans subvert macrophage IL-12 production by targeting ERK MAP kinase. J Immunol 1999;163:6403-6412. [PubMed: 10586030]

19. Kim SC, Tonkonogy SL, Albright CA, Tsang J, Balish EJ, Braun J, Huycke MM, Sartor RB. Variable phenotypes of enterocolitis in interleukin 10-deficient mice monoassociated with two different commensal bacteria. Gastroenterology 2005;128:891-906. [PubMed: 15825073]

20. Rada B, Leto TL. Oxidative innate immune defenses by Nox/Duox family NADPH oxidases. Contrib Microbiol 2008;15:164-187. [PubMed: 18511861]

21. Yap GS, Ling Y, Zhao Y. Autophagic elimination of intracellular parasites: convergent induction by IFN-gamma and CD40 ligation? Autophagy 2007;3:163-165. [PubMed: 17204853]

22. Kok K, Geering B, Vanhaesebroeck B. Regulation of phosphoinositide 3-kinase expression in health and disease. Trends Biochem Sci 2009;34:115-127. [PubMed: 19299143]

23. Al-Alwan MM, Okkenhaug K, Vanhaesebroeck B, Hayflick JS, Marshall AJ. Requirement for phosphoinositide 3-kinase p110delta signaling in B cell antigen receptor-mediated antigen presentation. J Immunol 2007;178:2328-2335. [PubMed: 17277138]

24. Dil N, Marshall AJ. Role of phosphoinositide 3-kinase p110 delta in TLR4- and TLR9- mediated B cell cytokine production and differentiation. Mol Immunol 2009;46:1970-1978. [PubMed: 19362372]

25. Patton DT, Garden OA, Pearce WP, Clough LE, Monk CR, Leung E, Rowan WC, Sancho S, Walker LS, Vanhaesebroeck B, Okkenhaug K. Cutting edge: the phosphoinositide 3-kinase p1 10 delta is critical for the function of CD4+CD25+Foxp3+ regulatory T cells. J Immunol 2006;177:6598-6602. [PubMed: 17082571]

26. Moayyedi P, O'Mahony S, Jackson P, Lynch DA, Dixon MF, Axon AT. Small intestine in lymphocytic and collagenous colitis: mucosal morphology, permeability, and secretory immunity to gliadin. J Clin Pathol 1997;50:527-529. [PubMed: 9378824]

27. Sollid LM. Intraepithelial lymphocytes in celiac disease: license to kill revealed. Immunity 2004;21:303-304. [PubMed: 15357941]

28. Fukao T, Tanabe M, Terauchi Y, Ota T, Matsuda S, Asano T, Kadowaki T, Takeuchi T, Koyasu S. PI3K-mediated negative feedback regulation of IL-12 production in DCs. Nat Immunol 2002;3:875881. [PubMed: 12154357]

29. Kuo CC, Lin WT, Liang CM, Liang SM. Class I and III phosphatidylinositol 3'-kinase play distinct roles in TLR signaling pathway. J Immunol 2006;176:5943-5949. [PubMed: 16670302]

30. Yu Y, Nagai S, Wu H, Neish AS, Koyasu S, Gewirtz AT. TLR5-mediated phosphoinositide 3-kinase activation negatively regulates flagellin-induced proinflammatory gene expression. J Immunol 2006;176:6194-6201. [PubMed: 16670329]

31. Aksoy E, Vanden Berghe W, Detienne S, Amraoui Z, Fitzgerald KA, Haegeman G, Goldman M, Willems F. Inhibition of phosphoinositide 3-kinase enhances TRIF-dependent NF-kappa B activation and IFN-beta synthesis downstream of Toll-like receptor 3 and 4. Eur J Immunol 2005;35:2200 2209. [PubMed: 15940673]

32. Papakonstanti EA, Zwaenepoel O, Bilancio A, Burns E, Nock GE, Houseman B, Shokat K, Ridley AJ, Vanhaesebroeck B. Distinct roles of class IA PI3K isoforms in primary and immortalised macrophages. J Cell Sci 2008;121:4124-4133. [PubMed: 19033389]

33. Booth JW, Telio D, Liao EH, McCaw SE, Matsuo T, Grinstein S, Gray-Owen SD. Phosphatidylinositol 3-kinases in carcinoembryonic antigen-related cellular adhesion moleculemediated internalization of Neisseria gonorrhoeae. J Biol Chem 2003;278:14037-14045. [PubMed: 12571236]

34. Levine B, Deretic V. Unveiling the roles of autophagy in innate and adaptive immunity. Nat Rev Immunol 2007;7:767-777. [PubMed: 17767194] 

A.
6 to 8 wk $(n=3)$
만 10 to 25 wk $(n=12)$
- 25 to $45 \mathrm{wk}(\mathrm{n}=15)$

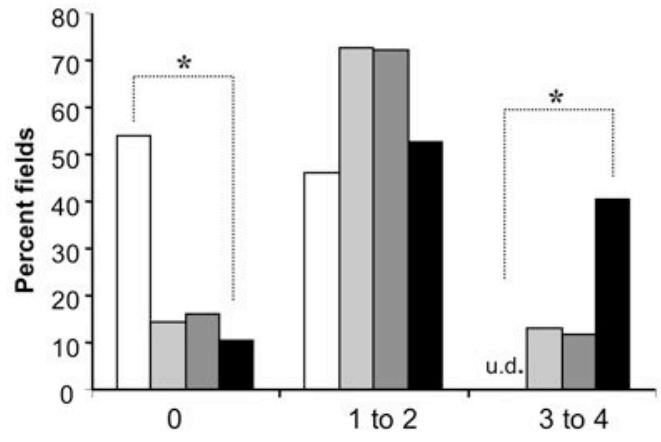

C.
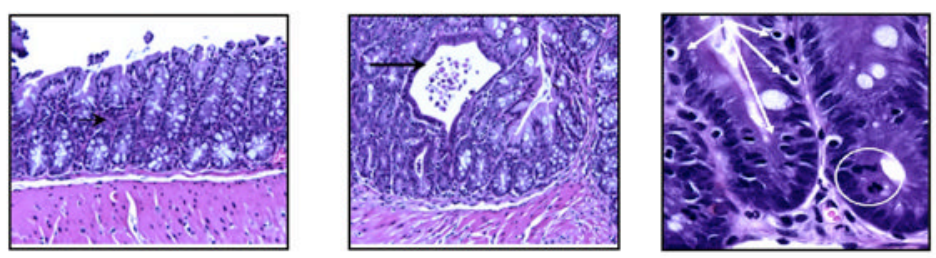

D.
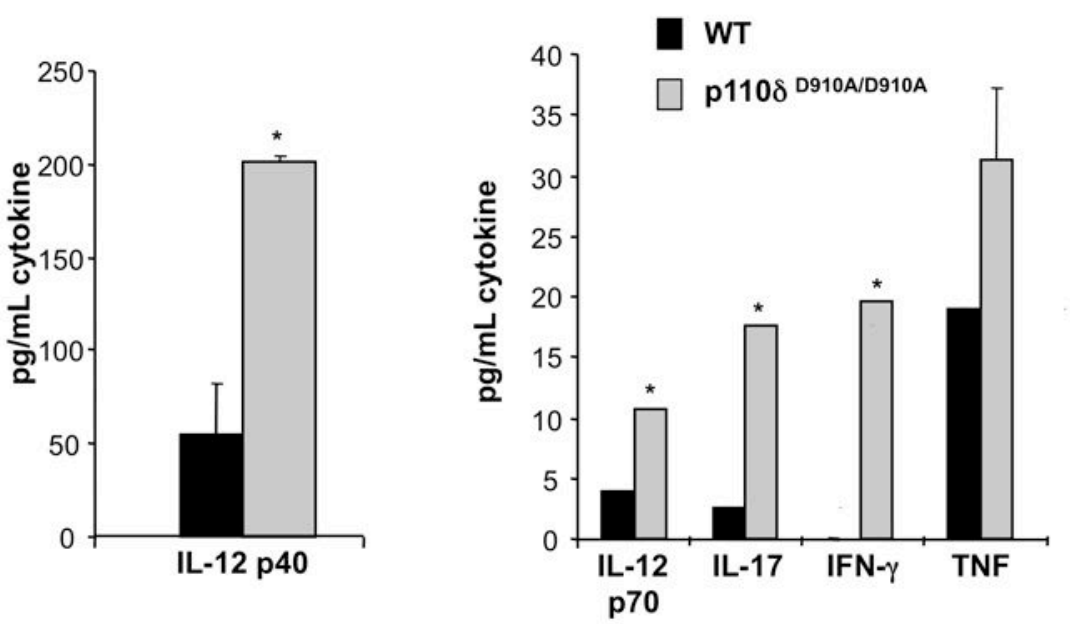

B.

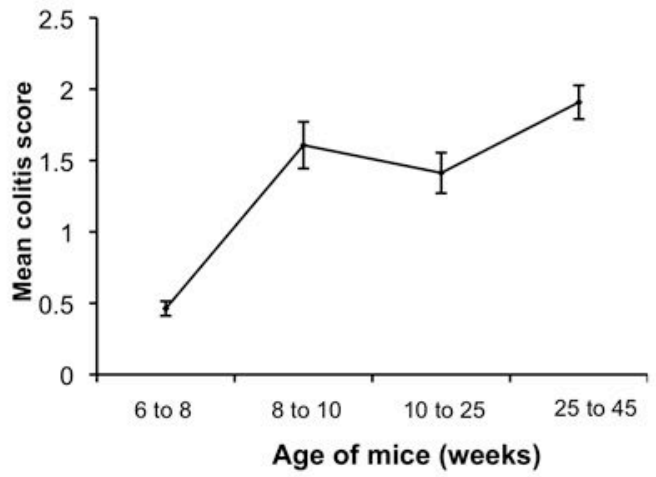

Figure 1. PI3K p1108 ${ }^{\mathrm{D} 910 \mathrm{~A} / \mathrm{D} 910 \mathrm{~A}}$ mice develop colitis

(A and B) Histological scores of colonic sections from WT and PI3K p110 $\delta^{\mathrm{D} 910 \mathrm{~A} / \mathrm{D} 910 \mathrm{~A}}$ mice at different ages. Results are represented as percentage of microscopic fields in each age group with score 0,1 to 2 or 3 to 4 (A); or mean colitis scores (B). ( ${ }^{*} p<0.05$ v. 25-45 WT week old mice) (C) Colonic sections from 10 week old PI3K p110d ${ }^{\mathrm{D} 910 \mathrm{~A} / \mathrm{D} 910 \mathrm{~A}}$ mice demonstrate leukocytic infiltration of the lamina propria (white circle) and intraepithelial lymphocytes (white arrows) in the crypts. Focal crypt abscesses were observed (black arrow). (D) Colonic explants from WT (black bars) and PI3K p1 10 $\delta^{\mathrm{D} 910 \mathrm{~A} / \mathrm{D} 910 \mathrm{~A}}$ (grey bars) mice were assayed for spontaneous secretion of cytokines. Error bars represent mean+SEM of 3 independent experiments. 
A.

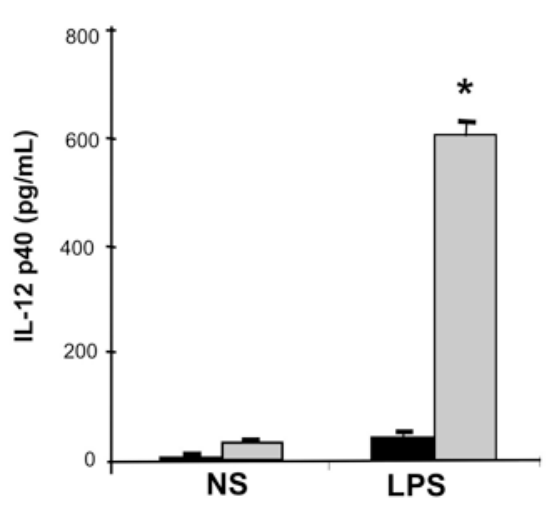

B.

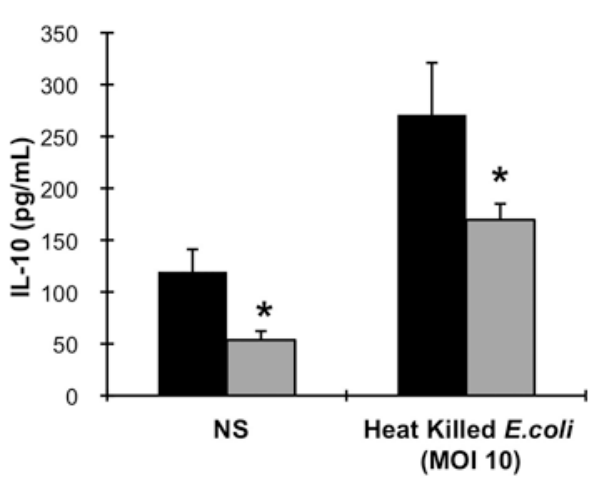

C.

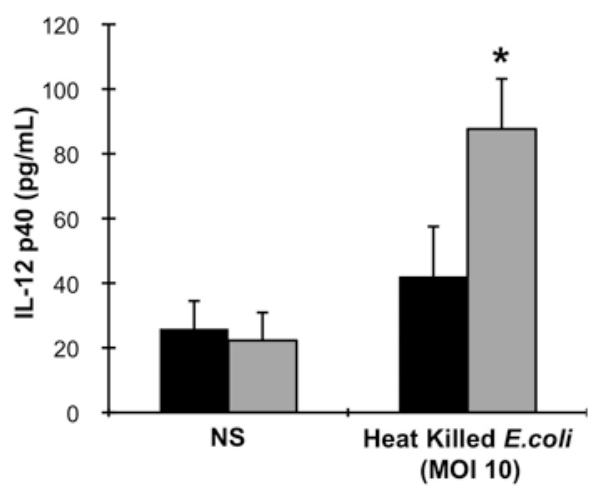

E.
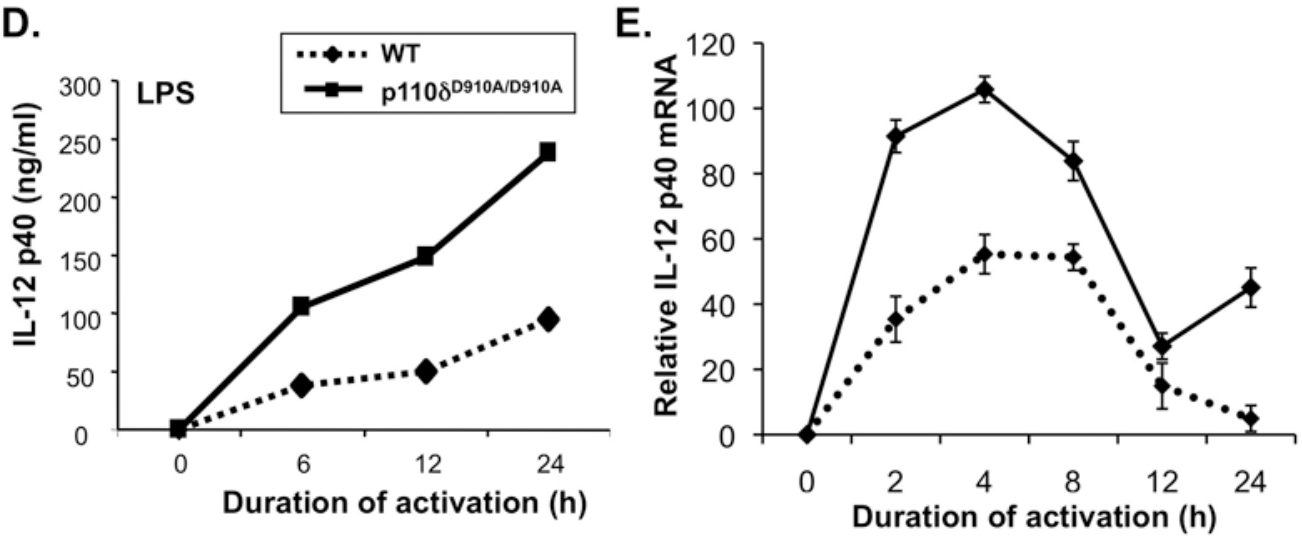

WT

$\square$ p1108

Figure 2. PI3K p110 $\delta^{\mathrm{D} 910 A / D 910 A}$ mice display enhanced expression of IL-12 p40

(A) Splenocytes from WT (black bars) and PI3K p110 $\delta^{\mathrm{D} 910 \mathrm{~A} / \mathrm{D} 910 \mathrm{~A}}$ (grey bars) mice were untreated (un) or stimulated with LPS $(1 \mu \mathrm{g} / \mathrm{ml})$ alone or LPS and IFN- $\gamma(10 \mathrm{ng} / \mathrm{ml})$ for 24 hours. IL-12 p40 was measured by ELISA. (B and C) Colonic macrophages from WT or PI3K p110d ${ }^{\mathrm{D} 910 \mathrm{~A} / \mathrm{D} 910 \mathrm{~A}}$ mice were stimulated with heat killed E. coli (mode of multiplicity 10) for 24 hours. ELISAs were performed to assess IL-12 p40 (B) and IL-10 (C) levels. (D and E) Bone-marrow derived macrophages (BMMs) from WT (black bars) and PI3K $\mathrm{p} 110 \delta^{\mathrm{D} 910 \mathrm{~A} / \mathrm{D} 910 \mathrm{~A}}$ (grey bars) mice were unstimulated (Un.) or stimulated with LPS (1 $\left.\mu \mathrm{g} / \mathrm{ml}\right)$ and supernatants analyzed for IL-12 p40 (D). PI3K p110d ${ }^{\text {D910A/D910A }}$ BMMs were harvested at each time point and IL-12 p40 (Il12b) mRNA (E) levels were assessed by real-time RT- 
PCR. Results are expressed as fold induction normalized to $\beta$-actin. Error bars represent mean + SEM of 3 independent experiments $\left({ }^{*} \mathrm{p}<0.05 \mathrm{v}\right.$. WT cells). 


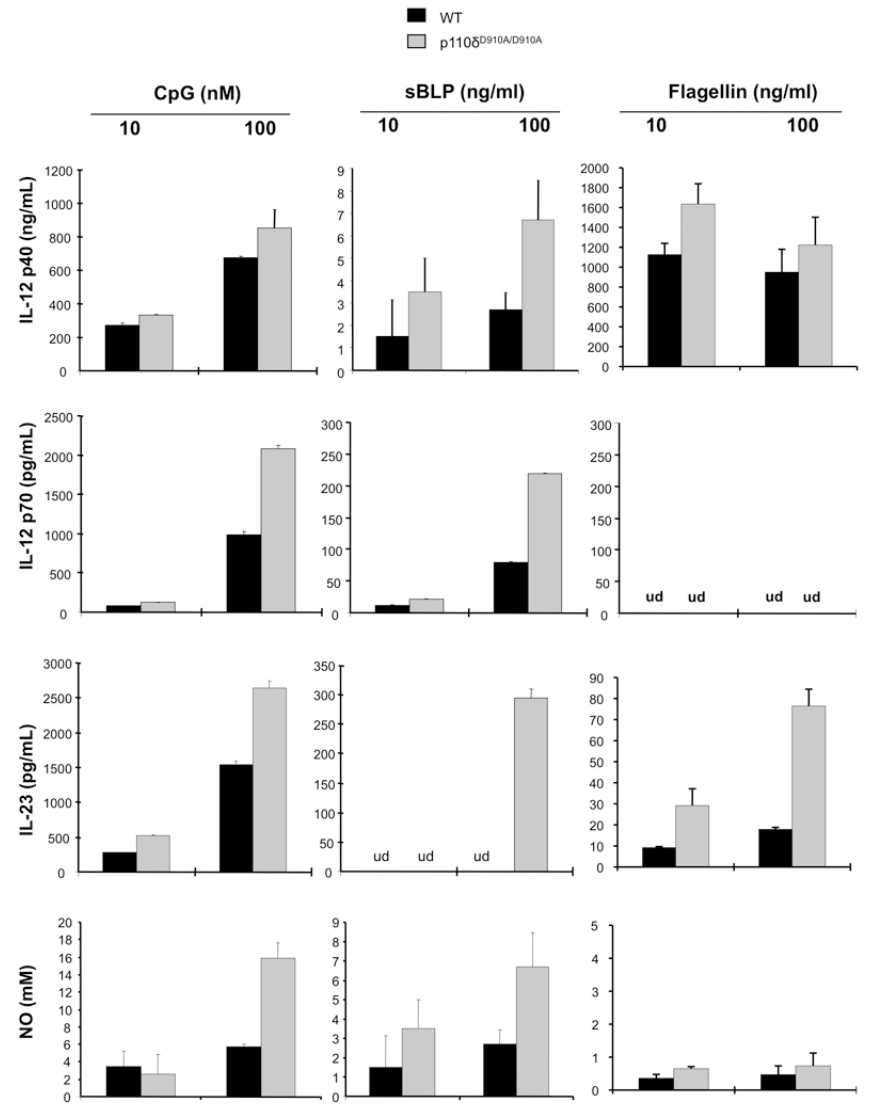

Figure 3. PI3K p110 $\delta^{\mathrm{D} 910 A / D 910 A}$ macrophages demonstrate heightened sensitivity to TLR stimulation

BMMs from WT (black bars) and PI3K p1 10 $\delta^{\text {D910A/D910A }}$ (grey bars) mice were stimulated with TLR9 (CpG), TLR2 (sBLP) or TLR5 (Flagellin) ligands for 24 hours. Supernatants were analyzed for IL-12 p40, IL-12 p70 or IL-23 secretion by ELISA and nitric oxide secretion by Greiss reaction. Error bars represent mean+SEM of 3 independent experiments. 


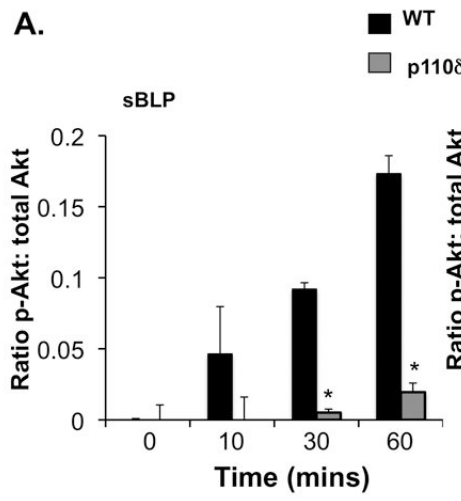
$110 \delta^{\mathrm{D} 910 \mathrm{~A} / \mathrm{Dg} 10 \mathrm{~A}}$

NT

B.
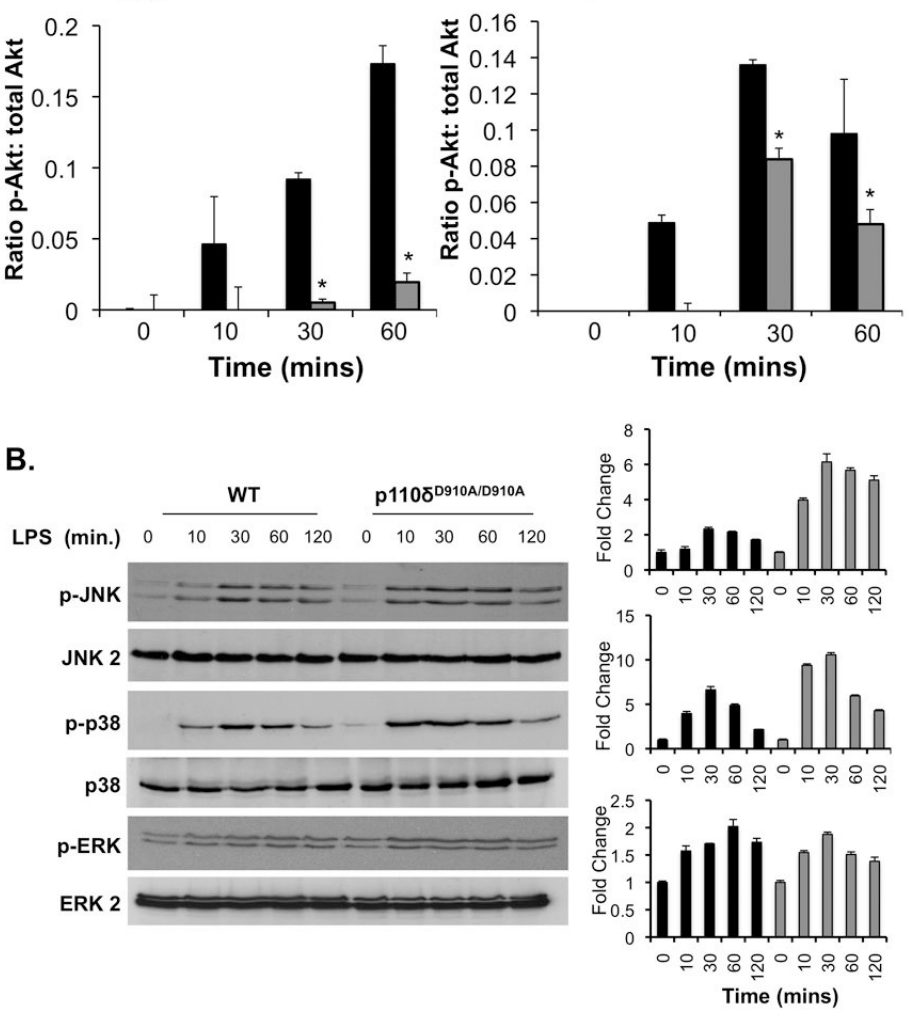

Figure 4. PI3K p110 ${ }^{\mathrm{D} 910 \mathrm{~A} / \mathrm{D} 910 \mathrm{~A}}$ macrophages demonstrate altered kinetics and magnitude of MAPK activation

(A) BMMs from WT or PI3K p110 $\delta^{\mathrm{D} 910 \mathrm{~A} / \mathrm{D} 910 \mathrm{~A}}$ mice were stimulated with (right) LPS (100 $\mathrm{ng} / \mathrm{ml})$ or (left) sBLP $(100 \mathrm{ng} / \mathrm{ml})$ for the indicated periods of time and phosphorylation of Akt (p-Akt) was assayed by ELISA. Results are presented as a ratio of p-Akt to total Akt. (B) BMMs from WT and PI3K p1108 ${ }^{\mathrm{D} 910 \mathrm{~A} / \mathrm{D} 910 \mathrm{~A}}$ mice were stimulated with LPS $(1 \mu \mathrm{g} / \mathrm{ml})$ for the indicated times. Whole cell extracts were analyzed for phosphorylation of MAPK (JNK, ERK, p38) by Western blot. Results represent mean+SEM of 3 independent experiments ( ${ }^{*} \mathrm{p}<0.05$ vs WT). 


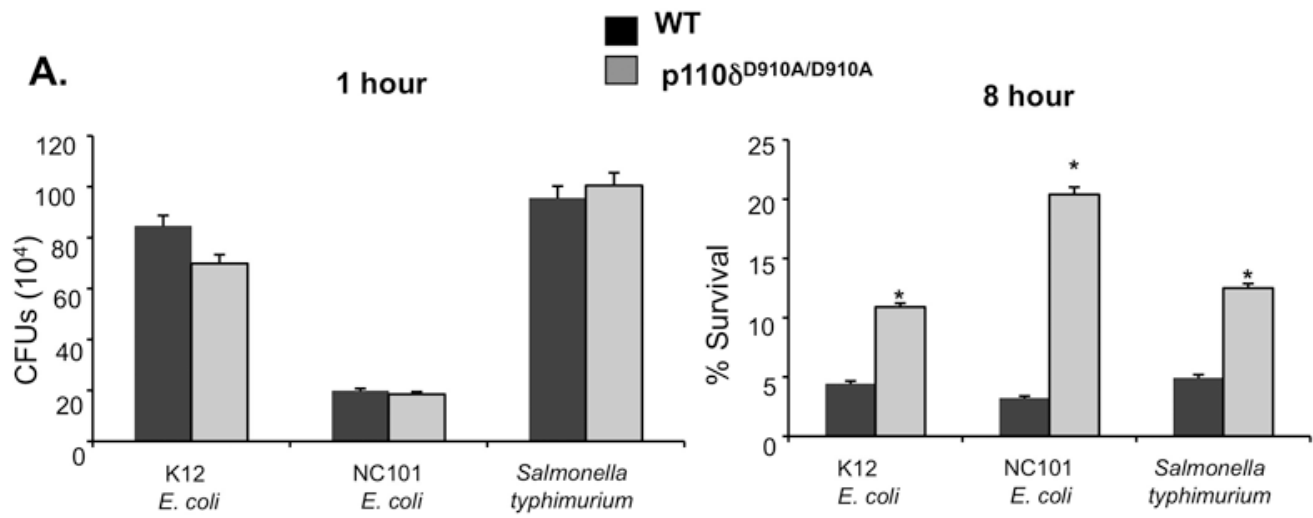

B.

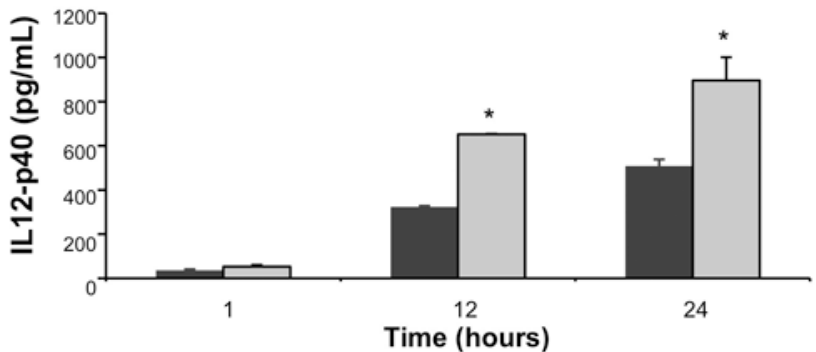

C.

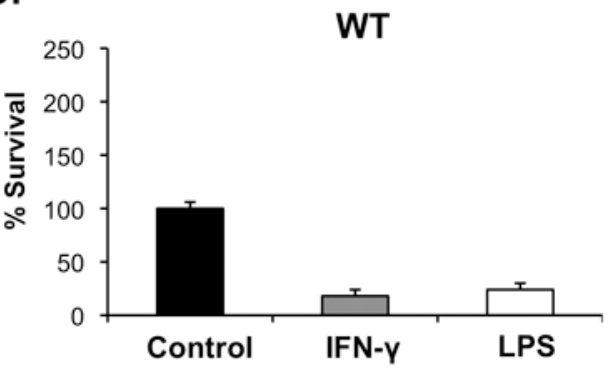

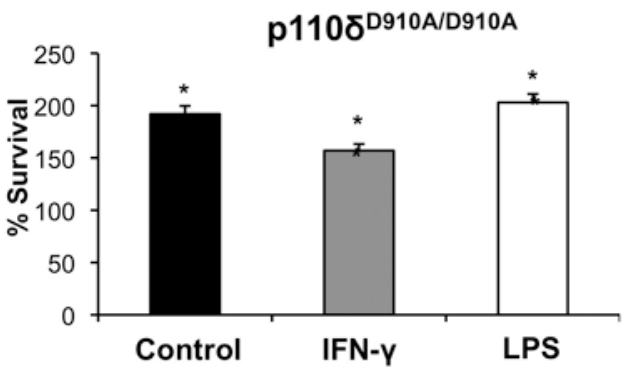

D.

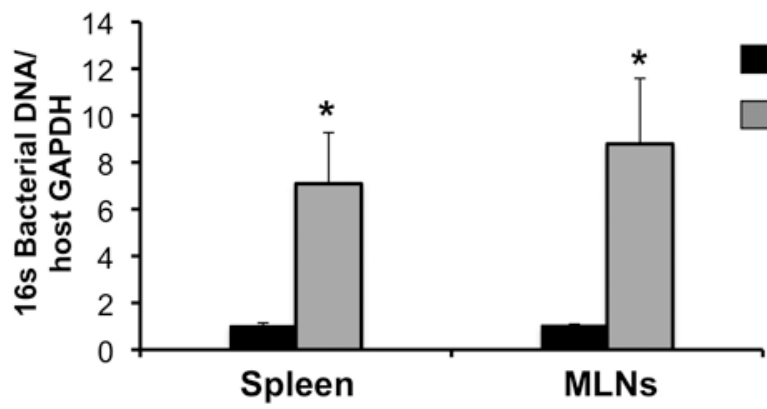

Figure 5. PI3K p1108 ${ }^{\mathrm{D} 910 \mathrm{~A} / \mathrm{D} 910 \mathrm{~A}}$ BMMs demonstrate defective bactericidal activity (A) WT and p110d ${ }^{\mathrm{D} 910 \mathrm{~A} / \mathrm{D} 910 \mathrm{~A}}$ BMMs were cultured with K12 E. coli. NC101 E. coli or S. typhimurium. No significant bacterial recoveries were seen 1-hour post-bacterial infection (left panel). P13K p110 $\delta^{\text {D910A/D910A }}$ BMMs demonstrate decreased bactericidal activity relative to wild type BMMs at 8 hours post-infection (right panel) (*p<0.05 v WT BMMs). (B) IL-12 p40 production by ELISA was assessed in P13K p110d ${ }^{\text {D910A/D910A }}$ BMMs infected with K12 E. coli. (C) BMMs were treated with LPS $(100 \mathrm{ng} / \mathrm{mL})$ or IFN $-\gamma(10 \mathrm{ng} / \mathrm{mL})$ prior to bacterial infection, and bacteria recovered from lysed cells 8 hours post-infection $(* \mathrm{p}<0.05$ vs WT BMMs). (D) Total bacterial DNA in spleen and mesenteric lymph nodes were detected by realtime PCR using primers for total 16S rRNA genes Primers for GAPDH were used to show 
loading control of host genomic DNA. Error bars represent mean+SEM of 3 independent experiments $(* \mathrm{p}<0.05$ vs. WT). 

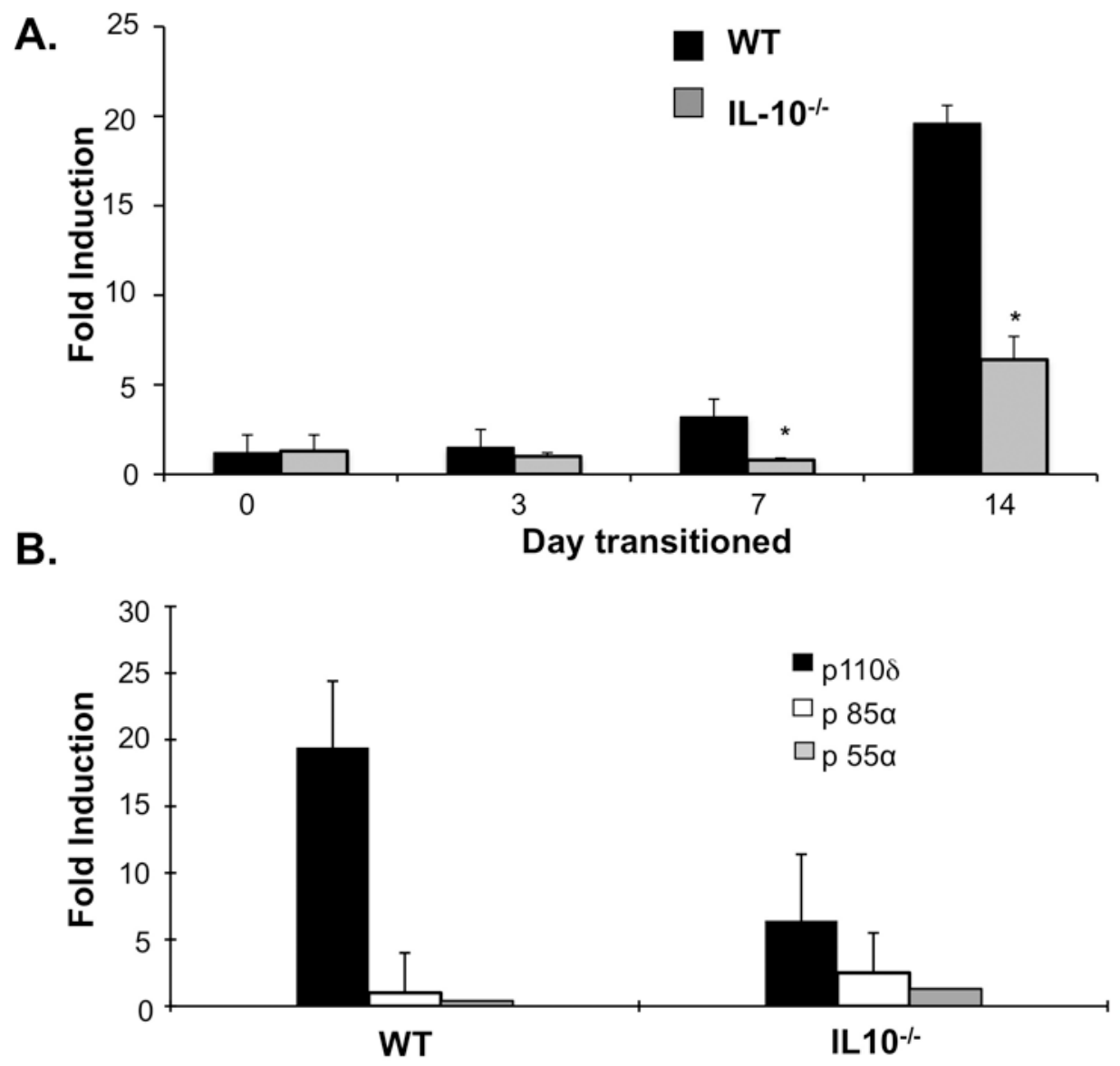

C.
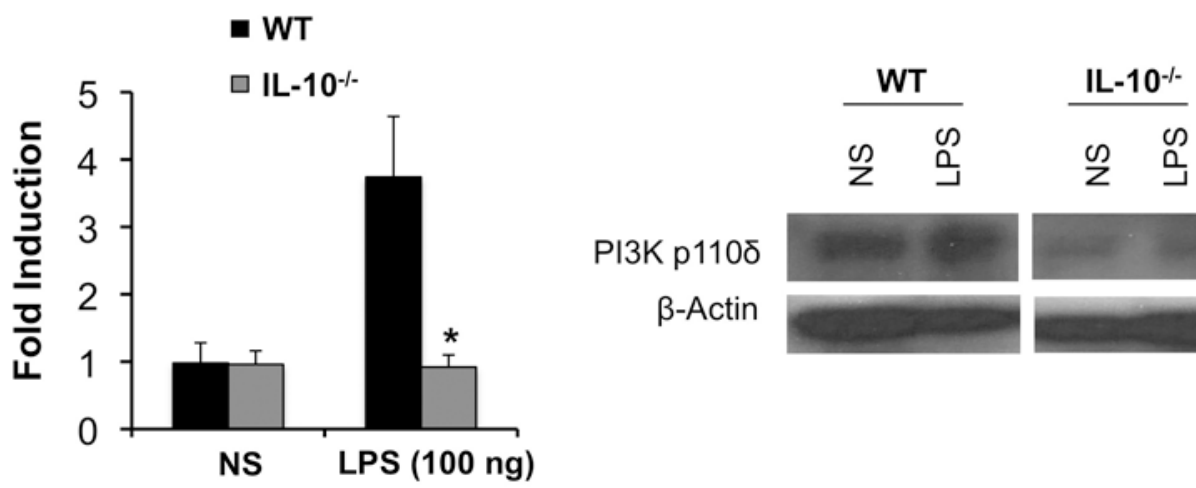

PI3K p110ס

$\beta$-Actin

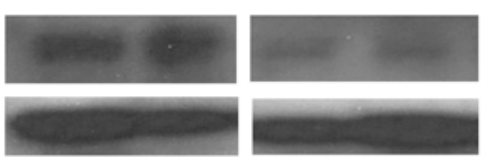

Figure 6. The enteric microbiota induces colonic PI3K p110d expression in WT but not colitisprone IL-10 ${ }^{-/-}$mice

Germ-free (GF) WT and IL-10 ${ }^{-1-}$ mice were transitioned to a specific pathogen free (SPF) microbiota. Colonic mRNA was isolated and expression of PI3K p110 $\delta$, p85a, and p55a mRNA was assessed by real-time RT-PCR. (A) Colonic PI3K p110d was determined in WT and IL-10 ${ }^{-1-}$ mice at $0,3,7$, and 14 days post colonization of GF mice with SPF microbiota (*p <

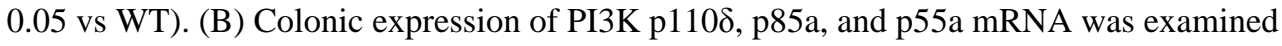
14 days post-transition of GF mice to SPF microbiota. Results are expressed as fold induction normalized to $\beta$-actin. Error bars represent mean+SEM of 3 independent experiments. (C) BMMs from WT and IL-10 $0^{-/-}$mice were stimulated with LPS (100 ng) for the indicated times. 
PI3K p110 mRNA levels were assessed by real-time RT-PCR (left panel). Results are expressed as fold induction normalized to $\beta$-actin and represent mean+SEM of 3 independent experiments $\left({ }^{*} \mathrm{p}<0.05 \mathrm{vs}\right.$ WT). BMMs from WT and IL $-10^{-/-}$mice were stimulated with LPS (100 ng) for 16 hours. Whole cell extracts were analyzed for PI3K $\mathrm{p} 110 \delta$ by Western blot (right panel). Results are representative of three independent experiments. 
A.

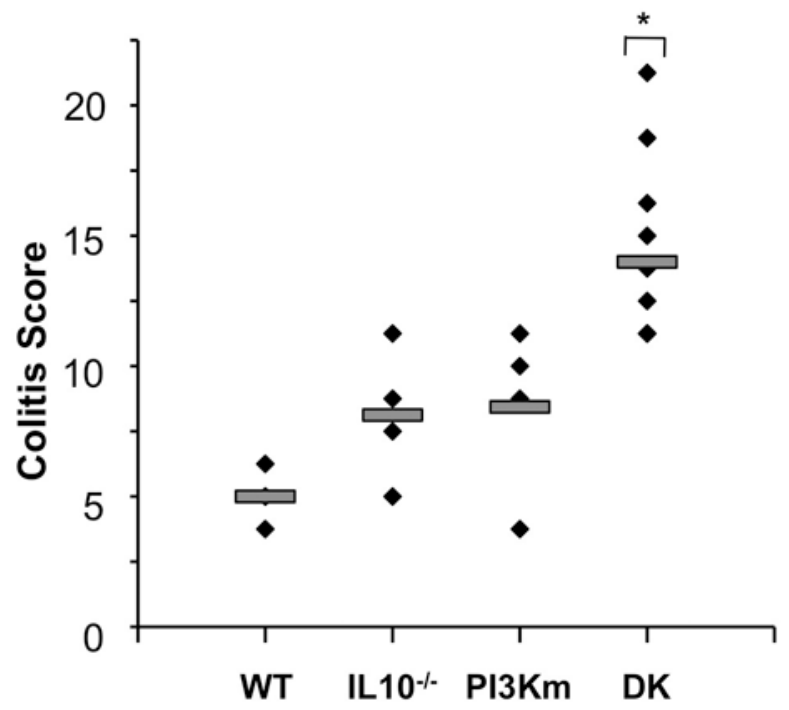

C.

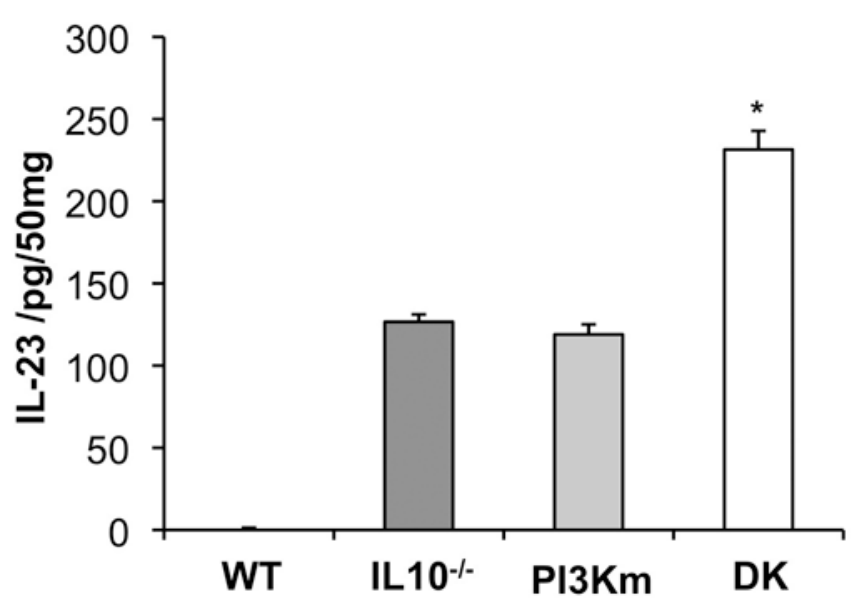

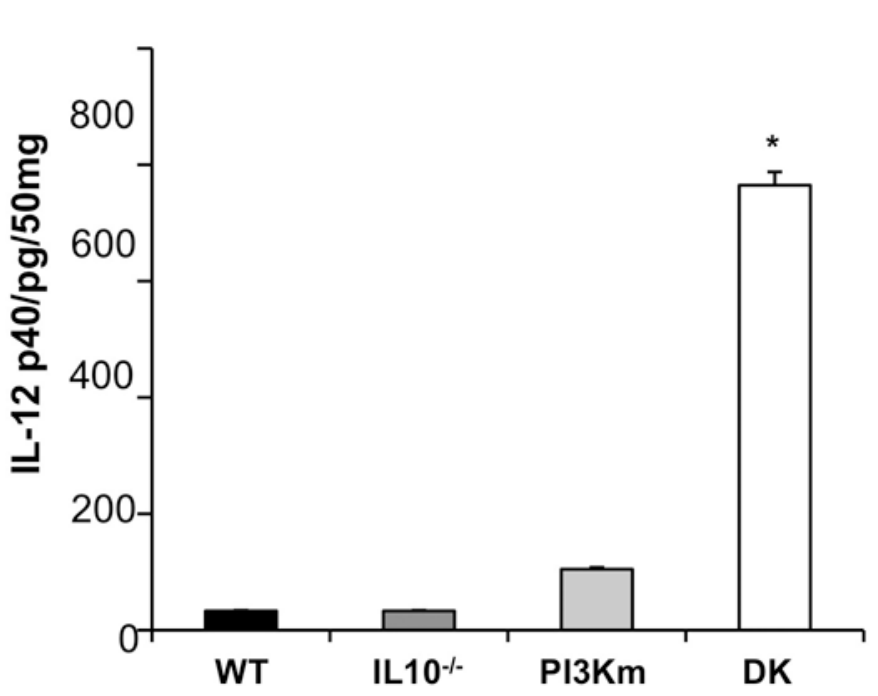

B.

D.

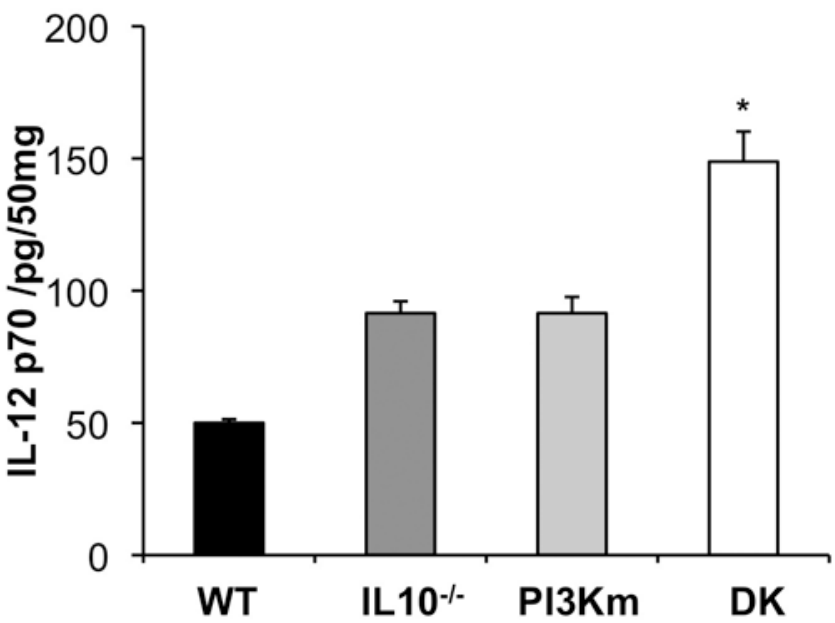

Figure 7. IL $-10^{-/-}$PI3K p110 ${ }^{\mathrm{D} 910 \mathrm{~A} / \mathrm{D} 910 \mathrm{~A}}$ mice exhibit severe colitis at an early age (A) Colitis scores were determined for 4-week-old IL-10 ${ }^{-/-} / \mathrm{PI} 3 \mathrm{~K}$ p $110 \delta^{\mathrm{D} 910 \mathrm{~A} / \mathrm{D} 910 \mathrm{~A}}$ (DK), WT, IL-10 ${ }^{-/-}$, and PI3K p110 $\delta^{\mathrm{D} 910 \mathrm{~A} / \mathrm{D} 910 \mathrm{~A}}(\mathrm{PI} 3 \mathrm{Km})$ mice using criteria established for IL- $10^{-/-}$mice $^{13}$ by a pathologist blinded to genotype (*p $<0.05$ vs WT). IL-12 p40 (C), IL-12 p70 (E) and IL-23 (D) protein in supernatants from colon explant cultures from IL-10 ${ }^{-/} / \mathrm{PI} 3 \mathrm{~K}$ p110 $\delta^{\mathrm{D} 910 \mathrm{~A} / \mathrm{D} 910 \mathrm{~A}}(\mathrm{DK}), \mathrm{WT}, \mathrm{IL}-10^{-/-}$, and PI3K p11 $\delta^{\mathrm{D} 910 \mathrm{~A} / \mathrm{D} 910 \mathrm{~A}}(\mathrm{PI} 3 \mathrm{Km})$ mice were analyzed by ELISA. Error bars represent mean+SEM of 3 independent experiments $(* \mathrm{p}<0.05$ vs. WT). 